\title{
Financial Relations in Flood Insurance: US Experience, use in Russia
}

\author{
Tatyana Miroshnikova ${ }^{1}$, and Natalya Taskaeva ${ }^{2}$ \\ ${ }^{1}$ Associate professor, Vladivostok State University of Economy and Service, Gogolya str., 41, Vladivostok, 690014, Russia \\ ${ }^{2}$ Associate professor, National research Moscow State Construction University, Yaroslavskoe highway, 26, Moscow, 129337, Russia
}

\begin{abstract}
A flood is a natural disaster that threatens the economy through the damage caused. Establishing an effective financial mechanism for assessing damage and providing flood insurance is becoming increasingly important. An analysis of the financial relationships between government and insurance organizations in the field of US insurance, related directly to the management system in flood-prone areas, allows us to develop recommendations for building an effective flood insurance system in Russia. Research into the costing of the US national flood insurance program and the appropriate level of subsidies for existing properties in high-risk flood areas is part of the scientific study of the interaction between insurance and government funding. The article provides an overview of the mechanism for the distribution of financial resources in areas prone to flooding. Proposals are presented regarding the creation of an effective flood insurance system in Russia, which will ensure the coordination of actions of various levels of government, scientifically grounded zoning in flooded areas, as well as the establishment of compulsory insurance of social, housing, and communal facilities in flood-prone areas.
\end{abstract}

\section{Introduction}

The presented research contains an analysis of the system of relations in the field of flood insurance in the United States, to assess the possibilities of forming effective insurance protection against these risks in Russia. In the context of globalization, the international distribution of the risks of natural disasters and natural disasters is becoming increasingly important.

The aim of the study is to develop recommendations for creating an effective mechanism for assessing damage and providing insurance in case of floods in Russia based on the experience of the United States.

The main task is to implement methods and tools that ensure the redistribution of risks and compensation for flood damage between the state and the insurance sector. At the same time, the coordination of their actions must be ensured. To substantiate the main directions of socioeconomic policy in eliminating the consequences of floods based on studying the experience of foreign property insurance against floods.

The greatest experience in solving this problem exists in the United States, where, since 1928, several dozen laws have been adopted that regulate certain aspects of flood protection. Currently, the US flood policy is based on the National Flood Insurance Program (NFIP), which since 1979 has been run by a specialized federal unit the Federal Emergency Management Agency (FEMA). The federal agency, directly or through commercial insurance companies, offers property owners government-guaranteed flood insurance policies. Since
1973, there has been a law providing for the compulsory purchase of an insurance policy by those who finance the construction or modernization of houses located in areas that are in the zone of possible floods [1].

According to the Center for the Study of the Epidemiology of Natural Disasters for the period 20002010 , floods account for $50.2 \%$ of the total number of natural disasters in the world and $42.7 \%$ of those affected [2]. Flood losses can be estimated at billions of dollars. Authors S. Bednaruk and E. Ovcharov point out that the damage from floods falls on the communal sector for $35 \%$, agriculture for $27 \%$, industry $14 \%$, transport links $8 \%$ and other 16\% [3]. Flood risk management issues were considered in the works of B.N. Porfirieva, N.P. Tikhomirova, I.M. Potravny, A.V. Shalikovsky, etc.

In Russia, 40-70 large floods occur annually. According to the Federal Service for Hydro meteorology and Environmental Monitoring, about 500 thousand square kilometers are prone to natural disasters. Floods with catastrophic consequences affected 150 thousand square kilometers, where there are about 300 cities, tens of thousands of settlements numerous economic facilities, more than 7 million hectares of farmland. The average annual damage from floods is estimated at 40 billion rubles. Powerful snow and rain floods occur on large Russian rivers almost every year. According to a study by the All-Russian Scientific Research Institute of Hydro meteorological Information - World Data Center, the total number of hazardous hydrological phenomena (floods and floods) in the first decade of the XXI century 
in Russia increased by 1.5 times compared to the $1990 \mathrm{~s}$. [4].

\section{Materials and methods}

The study is based on the concept of systematic and integrative flood management. The work uses the methods of systemic, logical, historical, comparative, statistical, analysis, as well as reference forms for studying information.

This article analyzes and evaluates the flood insurance systems in America that have great significance to Russia. The most serious flood in American history occurred in the Mississippi River in 1927, causing huge economic losses. In 1968, the United States Congress passed the National Flood Insurance Act (NFIA), formulated the National Flood Insurance Plan (NFIP) and established the National Flood Insurance Fund to compensate for the lack of a flood insurance market [5]. Developed countries implemented flood insurance systems early and have accumulated abundant experience.

Integration of international experience can provide the necessary assistance in the development of measures for the prevention and elimination of the consequences of emergencies caused by floods. Floods cause huge material damage to the national economy of the floodprone region.

Each country has its characteristics of property flood insurance. The degree of development of the insurance system largely depends on the level of the legal, socioeconomic situation of the country and its ability to control the activities of participants in the insurance market.

The leading countries in terms of the level of development of the insurance market are: the USA, Japan, China, Great Britain, Germany and France. Among these countries, the undisputed leaders in terms of the level of development of the insurance market are the USA and Japan.

The leadership of the United States in the field of the effectiveness of the organization of insurance protection against natural disasters and the distribution of the global insurance fund in case of natural disasters can be explained by the significant technological experience of this country in the organization of insurance protection against natural disasters. The US dominates the natural disaster insurance market.

Research on the issues of determining the costs of the national flood insurance program and determining the required level of subsidies for existing properties in areas with high flood risk are one of the elements of the scientific study of the system of interaction between insurance and public assistance to the program.

Until 1968, the US federal government independently controlled the flooded areas. At the same time, there was an increase in funding for federal projects and subsidies for damages if insured events. The federal aid mechanism required significant financial resources. The financing issue was resolved through the federal funds' mechanism, which was the most effective. Since insurance compensation was virtually inaccessible to the private sector due to the scale of the disasters, Congress was asked to ensure interaction of insurance and government assistance through the Federal Flood Insurance Program. The program involved the integration of three components: cooperation between the federal government, state and municipal governments, and the private property insurance system. The private insurance system is unable to adequately identify all flood hazard areas, and the costs of conducting hydrological surveys do not match the real capabilities of the private sector. Thus, the system of financial relationships included a mechanism for the formation of Federal funds; specialized insurance funds at the regional level; federally subsidized insurance, directly determined by the financial policy of municipalities in the field of flood management; as well as funds of insurance companies [6].

\section{Results}

The problems of financial support were associated with the organizational and regulatory aspects of the formation of the national insurance fund, the deposit payments of the Program Director, the existing premium rates differentiated by the main types of costs accounted for in them. The 1968 (National Flood Insurance Act) and 1973 (Flood Disaster Protection Act) formulated the main goals and objectives of the national flood insurance program. In accordance with the specified legal documents in the US Treasury, the Director of the Federal Emergency Management Agency (FEMA) was the Director of the Flood Insurance Program. The presented acts determined the basic conditions for the creation of a national flood insurance fund, which was a separate account, different from other accounts and funds available to the Director without established annual limits. The director was authorized to encourage, support and assist insurance companies and insurers in the formation of the pool. He provided insurance coverage if floods, taking responsibility for the issue.

Thus, the National Flood Protection Program was the fundamental document governing the formation of a fund for financing the insurance sector. The National Flood Insurance Fund was the main source of federal funding for the insurance industry.

The formation of financial resources for the national flood insurance program was provided by the following funds:

- National Flood Insurance Fund - NFIF

- Pre-Disaster Mitigation Fund - PDMF

- National Flood Mitigation Fund

- National Insurance Development Fund - NIDF

- Working capital Fund - WCF

In addition to the funds presented, there were specialized funds and programs that are sources of funding for the NFIP:

- Disaster Relief fund - DRF;

- Disaster Assistance Direct loan Program subsidy and administrative expenses - DADLP;

- Emergence Flood and Shelter (EFS); 
- Inspector General - OIG;

- Salaries and Expenses - S\&E;

- Emergency Management Planning and Assistance EMPA;

- Emergency Management Performance Grants.

The priority area for using the funds of specialized funds was to support the management personnel of the Federal Emergency Management Agency FEMA. In particular, the Disaster Relief Fund financed the activities of 2,187 employees, 266 employees were allocated funds from the National Flood Insurance Fund; 187 employees were financed from the Working capital Fund and 1704.5 were supported by the Salaries and Expenses and Inspector General Funds.

Emergency management agencies in several states received grants under the Emergency Management Performance Grants (EMPG) program, which was funded by transfers from the Disaster Relief Fund (DRF) and the Pre-Disaster Mitigation Fund (PDMF) [7].

\section{Discussion}

National Flood Insurance Fund - The NFIF is the main source of funding and subsidies for the National Flood Protection Program. The fund was created in 1968 under the National Insurance Act and established by the US Treasury. The income from its activities and collected insurance premiums are deposited in this fund.

Administrative and national program costs, including agent commissions, claims payments, employee salaries and employee training, are paid by this fund. To ensure a smooth payment process for claims in cases of significant flood damage and insufficient accumulated funds of policyholders in the fund, the national program is supported by borrowing funds. Borrowing is done from the US Treasury. The National Program has the authority to borrow up to $\$ 1$ billion. Borrowing from the US Treasury most often occurs in cases of refunds at subsidiary rates. The use of these rates provides for the payment of a premium amount than the cost of losses payable under the insurance policy. Such a mechanism, in turn, leads to a shortage of funds in the National Fund, which are necessary to cover the full cost of insurance at subsidized rates, which causes the allocation of funds to the Fund by the US Congress. However, insurance of old structures at subsidiary rates was carried out with the aim of stimulating the reconstruction of buildings, structures and the construction of new facilities according to the standards of the national flood insurance program NFIR.

Flood Protection Act 1973 expanded the powers of the national program to issue subsidiary grants. Since 1987 to 1992, borrowing from Congress reduced the stocks of the National Insurance Fund by $\$ 415$ million [8]. Congressional appropriations were first required in 1981 to reimburse fund borrowings. The program has received an appropriation to reimburse annual borrowings up to and including 1986. The total amount borrowed from the Treasury until 1986 was $\$ 1.2$ billion, which was reimbursed through a series of appropriations. During this period, it was only in 1983 and 1984 that there was a negative operating result. From 1987 to 1996, negative operating results occurred in 1989, 1990, 1992, 1993, 1995, and 1996.

As noted earlier, until 1981, no action was taken regarding the level of subsidies available to existing properties in areas with high flood risk. Consequently, program costs inevitably exceeded income. In 1981, the administrator of the FIA (Federal Insurance Administration) set the goal of creating the program - to achieve self-sufficiency of the program relative to the average annual level of losses (1988 was taken as the base year).

Continuing legal subsidies existing properties in areas of high flood risk identified actuarial sustainability as an unrealistic goal for this pillar of the flood insurance program. The term "self-sustaining" means that in years when the loss from the occurrence of the insured event is less than the accepted average value, the program creates a surplus necessary for use in the period when the loss from the disaster exceeds the average value. However, consider that that the premium for existing buildings of that period regularly rose to their real value, it became higher than the premiums paid for new construction, but still amounted to $38 \%$ of the total risk premiums. The latter, in turn, account for approximately $35 \%$ of the total income of the NFIP (National Flood Insurance Program) at present. The consequence of the lack of bonus funds was that there was no possibility of accumulating catastrophic program reserves that would reduce the need to borrow funds from the Treasury. Insufficient premiums made it difficult to reimburse the borrowed funds from the NFIP (National Flood Insurance Program) to the funds [9].

However, with the statutory subsidy rate from 1986 to 1995 , the program operated with a positive cash flow balance. However, since December 1993, the National Flood Protection Program (NFIP) borrowed \$ 11 million in Treasury funds to pay for claims. The borrowed funds were reimbursed to the funds in six months. The consequence was that during the four budget years from 1993 to 1996, the program lost more than \$3.4 billion. Beginning in July 1995, the program resorted to borrowing from the Treasury. The borrowing rate reached \$917 million in June 1997. In March 1998, their level was reduced to $\$ 810$ million, including $\$ 45$ million in interest payments. The outstanding borrowing as of April 30, 1997, was $\$ 880$ million.

It should be noted that federal expenses, including salaries, as well as costs associated with flood mapping and flood management activities before 1986 were paid by an annual appropriation from the US Congress. Between 1987 and 1990, Congress required payment of program costs on bonus streams, excluding those costs in the rate structure. These actions resulted in losses of approximately $\$ 350$ million. Since 1990 , a federal tax of \$25 (hereinafter referred to as \$30) has been used to cover most of the costs, including salaries and miscellaneous costs [10].

The National Flood Insurance Fund was formed at the expense of three sources - deposited funds from the sale of insurance policies by agents to property owners; loans from the US Treasury; - appropriations from 


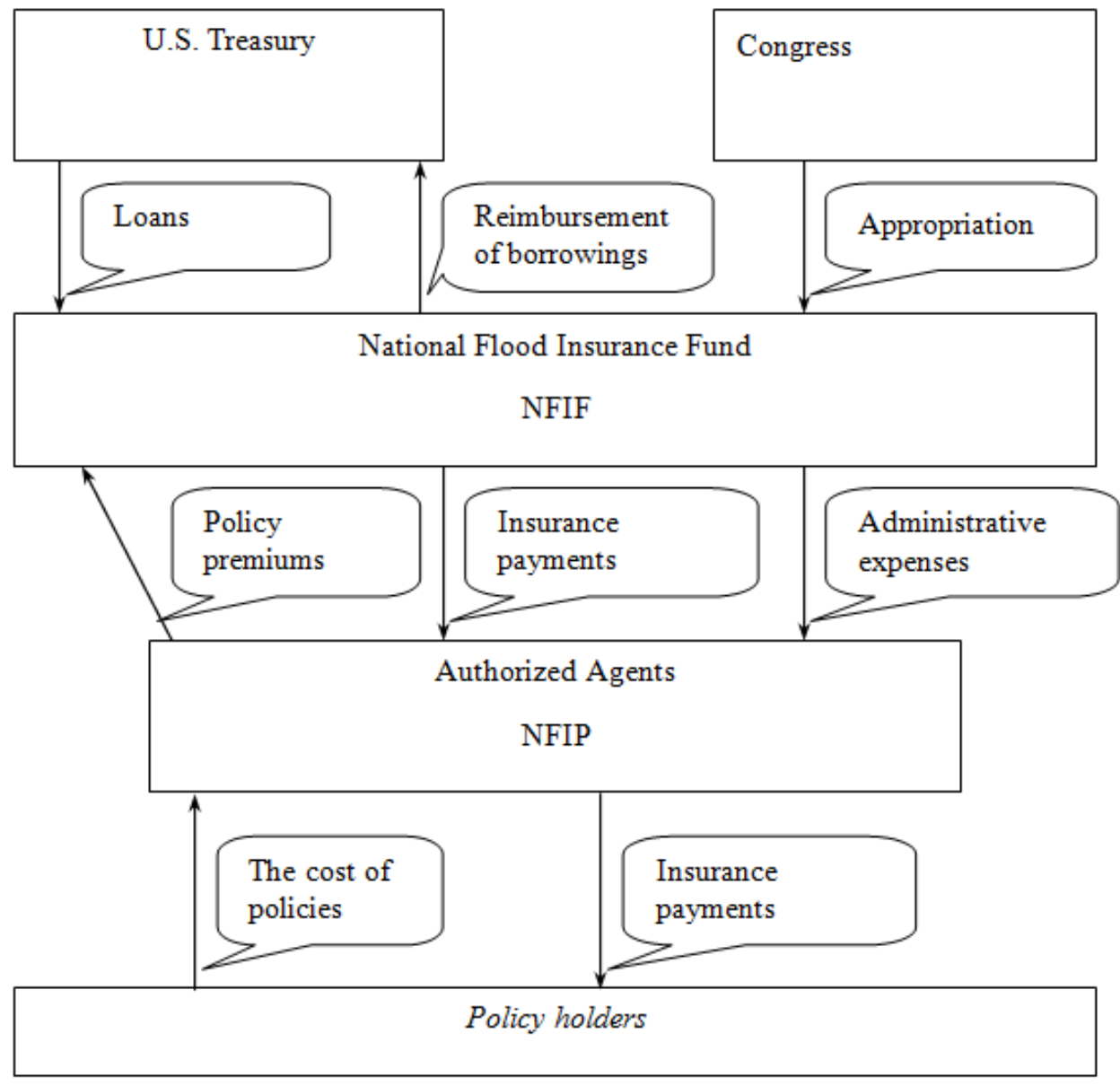

Fig. 1. Financial Relations in Flood Insurance: US experience.

Congress. The fund was spent on insurance payments, reimbursement of borrowings to the Treasury, and administrative and operating costs. Let us represent schematically the cash flow in the implementation of the national flood insurance program in Figure 1.

The director of the national flood insurance program applied for help from the National Flood Mitigation Fund. The volume of appropriations for one financial year could not exceed 1,500 thousand dollars for the purposes of the planned aid grants. The amount of the grant could not exceed 150 thousand dollars at the state level and 50 thousand dollars for any region. The volume of all grants attributable to one state, a certain territory or a region in a given state could not exceed 300 thousand dollars. The total amount of financial assistance for the five-year period was not to exceed \$20 million. The program director presented a report on the funding generated.

Regulatory and legal documentation defining the financing of the flood-prone areas management system accompanying the national flood insurance program:

Financial Assistance / Subsidy Arrangement (October 1, 1999)

Mortgage Portfolio Protection Program Agreement (October 1, 1999)

Flood Protection Act 1973 established the purchase of flood insurance as a prerequisite for all types of mortgages located in hazardous flood zones. The 1994 Flood Insurance National Reform Act focuses on creditors' consent to participate in the program.

Mortgage portfolio protection program Agreement MPPP assists companies involved in mortgage loans in building a portfolio of loans in accordance with flood insurance requirements under the Flood Disaster Protection Act of 1973. Under this program, all claimed mortgage debtors seeking flood insurance must be incentivized to obtain a standard flood insurance policy from local agents. In cases where the lender discovers after the disbursement of the loan that some of the loans in the portfolio are defined for an area located in a special hazard zone and this was not the basis for insuring this property, MPPP may oblige lenders or their companies to purchase the required flood insurance. If an insured event, the policy must be reissued if the insurance rate was incorrectly determined for the property located in the given territory. In addition, the amount of insurance coverage must be changed if it does not match the rental amount of the building [11].

An equally important document defining the terms of loans in flood-prone areas is the presented rules.

Final Rule for loans in Areas Having Special Flood Hazards

Rules for the implementation of loans in areas in flood risk zones. 


\section{Financial Control Plan}

A plan for exercising control over financial activities, which establishes requirements for financial reporting, payments, rates.

* Federal Financial Institution Examinations Council Act of 1974

Appraisal report of the Federal Financial Institute.

To manage loan capital, financial institutions coordinate the activities of federal agencies that regulate credit institutions that are not entitled to make loans secured by property located in special danger. Flood insurance for these areas is provided for by the 1968 Act.

In the context of the problem under consideration, one can single out the main forms of state support for the flood insurance system.

1. Providing loans to property owners from the Small Business Support Administration.

2. Provision of funds to reimburse the costs of resettlement of entities.

The insurance industry's interaction with the public assistance system for most flood disasters is to provide property owners with loans from the Small Business Administration (SBA) after an emergency occurs. Subjects unable to repay the SBA loan are eligible for individual grants from the Federal Emergency Management Agency (FEMA). Their amount is limited within the established limits and covers the costs of essential activities.

The next form of Federal support is the "buyout" program for the allocation of funds for resettlement. It consists in the provision of funds if a flood to cover the costs of relocation of subjects affected by destruction to other territories to avoid losses from a possible re-flood. The 1994 Act legalized the possibility of receiving federal assistance only on the condition of purchasing an insurance policy. The adoption of this provision was necessary due to the excess of payments under the buyout program, which reduced the incentive to purchase policies of the national flood insurance program. Thus, insurance has become the preferred alternative to federal support.

Flood insurance coverage is the preferred method over a loan or grant. At the same time, the government's policy of cutting subsidies increases premiums to higher levels, which in turn increases the demand for alternative forms of insurance that are ultimately more expensive.

The issues of financial relationships deserve attention from the standpoint of the consistency of economic monetary relations of the federal level and the sphere of private insurance. Since 1977 the insurance industry acted as the financial agent of the national insurance program in various ways. One of the methods of such involvement of private insurance companies was the WRITE YOU OWN (WYO) program - "The Right of Your Own Signature". Under this program, a private insurer sells and maintains a federally signed flood insurance policy on its behalf, retaining a premium percentage. The participating companies sign the WYO agreement annually. It defines the responsibilities of insurers and the federal government. WYO companies are required to comply with the standards defined in the WYO Program Financial Control Plan, which covers all aspects of their operations, including operational management and financial reporting.

Representation of WYO in the Program Control Administration operates through the Institute's Flood Safety Committee for Residential and Business Facilities and through its representation on the WYO Standards Committee. In addition, the National Flood Insurance Committee acts as an advisory group representing insurance agents selling and servicing NFIP policies.

The Community Assessment System (CRS) was created by the FIA in 1990 as a mechanism for recognizing and rewarding communities located in flood-prone areas. There are ten CRS classes. First class requires the most credit points and ends up with a correspondingly significant reduction in premium. The community that does not apply to the CRS program or does not receive the minimum number of credit points will receive 10th grade.

The WYO method is also used in the implementation of the MPPP program - Mortgage portfolio protection program Agreement. In this case, the unchanged company payments provided by the Financial Assistance and the Subsidy Agreement for all policyholders apply. Payments made by WYO under WYO Financial Assistance and MPPP Grant Agreements cannot be used as payments to credit institutions, mortgage companies, or similar entities. US National Flood Insurance policies using the MPPP program can only be valid for one year. Under the terms of the MPRR, insurance coverage for buildings and property is used in the amount of $\$ 250,000$ and $\$ 100,000$, respectively. However, under the Emergency Program, the insurance property limit is $\$ 35,000$ and $\$ 10,000$, respectively [12].

\section{Conclusion}

The study of financial flows that ensure the implementation of the national flood insurance program is relevant from the point of view of using foreign experience in domestic concepts for the development of the flood insurance industry. Due to insurance compensation, the disaster aid expenditure of the American government is annually reduced by one-third, effectively remedying victims' property losses and serving as an important source of funds for after-disaster reconstruction [13].

The presented regulations, agreements and guidelines define the funding mechanism for the flood management system and accompany the implementation of the national flood insurance program in the United States. The key points in this area of research is the study of financial institutions that coordinate the activities of federal agencies that regulate the functioning of credit institutions. The processing of information on the funds of funds operating under the national flood insurance program and the directions of their use, as well as a study of the dynamics of congressional appropriations in order to reimburse fund borrowings makes it possible to 
assess the feasibility of insurance in the context of an effective alternative to federal assistance [14-15].

At present, the organization of insurance of risks of natural disasters in Russia is ineffective. The ratio of the damage paid by the global insurance market from natural disasters that occurred on the territory of Russia to the volume of insurance premiums paid by the country's policyholders in 2002-2009 and in 2011 it was close to 0 .

In terms of the technological efficiency of organizing insurance of risks of natural disasters, Russia is several times behind the countries of Europe and Asia, and the United States in 2012 - several dozen times.

In the Russian Federation, compensation for flood damage is covered mainly from budgetary financial reserves. One of the alternative ways to reduce the share of state participation in compensation for damage from natural disasters is insurance of natural risks.

However, flood risk insurance in Russia, especially in Siberia and the Far East, plays an extremely small role. Thus, compensation for damage from catastrophic floods in eastern Russia in 2002 from insurance companies amounted to only $2-3 \%$ of the total damage, although in developed countries such payments reach $80 \%$. Natural disaster risk insurance in Russia is usually included in a property insurance policy. Insurers use the understated catastrophic part of the premium in terms of the ratio to real risks, to ensure current expenses and payments, and not to create reserves.

The problem of private property insurance in floodprone areas is an urgent problem of the present time. The issue of environmental insurance is directly related to the accumulation of reliable information when establishing insurance rates and the value of insurance premiums and determining the range of insured and accounted objects. Now, data on damage by industry are not taken into account. Agriculture, roads and bridges, housing and communal services are most susceptible to floods. Until 1993, the dominant form of ownership was state ownership. After privatization, practically all federal roads, communication lines, and facilities of federal departments' units remained under federal jurisdiction in the flooded areas. Municipal property most often includes roads, engineering structures, housing, and communal services. On average, in the context of forms of ownership, the share of state and municipal property accounts for $52 \%$ of the total volume of economic damage from floods.

Government funding remains the only reliable source of funding for the consequences of natural disasters in the face of real weakness in insurance. The main problem of Russian insurers is low business capitalization, which makes it impossible to work with large risks. This is complicated by the lack of understanding by the population of the country of the meaning of insurance as a compensation mechanism.

There is an increase in the share of enterprises of other forms of ownership, mainly joint stock companies. Analysis of data on damage and its compensation from various sources shows that there is a significant gap between them. Losses are not fully covered even for the damaged objects of federal property. The organization of property insurance in the state and municipal sectors of the economy depends on the availability of funds in the budgets of the respective levels of government. It is advisable to develop and implement measures to ensure the redistribution of risks for federal, regional and municipal property, as well as the development of a differentiated tariff depending on the actual exposure to risk. At the same time, a high level of coordination of actions of various levels of government should be ensured. There is a need to rank the types of economic activities based on their economic feasibility and social significance for areas regularly exposed to flooding. In particular, the rationale for finding social facilities in flood zones. Conducting various economic activities in these conditions stems from the understanding of the inevitability of economic damage from floods and the ability of executive authorities at different levels to stimulate insurance activities in flooded areas.

\section{References}

1. Mortgage portfolio protection program Agreement (MPPP), Issued by FEMA (1999)

2. S.A. Davis, Business Depth-Damage Analysis Procedures, Research Report 85-R-5, Ft Belvoir, VA: Institute for Water Resources, US Corps of Engineers (1985)

3. M.A. Greenaway, D.I. Smith, ANUFLOOD Field Guide, Canberra: Centre for Resource and Environmental Studies, Australian National University (1983)

4. S.J. Appelbaum, Determination of Urban Flood Damage, Journal of the ASCE, Water Resources Division, 111 (3), 269-282 (1985)

5. Yiqiu Jiang, Yong Luo, Xiaofeng $\mathrm{Xu}$, Flood insurance in China: recommendations based on a comparative analysis of flood insurance in developed countries, Environmental Earth Sciences, 78, 93 (2019) DOI: 10.1007/s12665019-8059-9

6. Financial Assistance / Subsidy Arrangement, Issued by FEMA (1999)

7. E.D. Pasterick, The National Flood Insurance Program (1998)

8. Report to Congress on the National Flood Insurance Program (1998)

9. H.L. Leiking, T.L. Hayes, National Flood Insurance Program and Flood Insurance Rate Review (30 November 1998)

10. Write Your Own Company Arrangements (1983)

11. Guide to Answers to Questions about the National Flood Insurance Program, Issued by FEMA

12. Mandatory Purchase of Flood Insurance Guidelines

13. See Technical Report "A chronology of major events affecting the National Flood Insurance 
Program beginning with the year 1824 through January 2006", FEMA (2005)

14. C.P. Jones, W.L. Coulbourne, J. Marshall, Jr.S.M. Rogers, Evaluation of the National Flood Insurance Program's Building Standards [Electronic resource], Prepared under subcontract to the American Institutes for Research as part of the 2001-2006 Evaluation of the National Flood Insurance Program Available at: http://www.fema.gov/business/nfip/nfipeval.shtm

15. U. S. Code Sect. 4001 (d)-(e) (2000) (declaring the purpose of national flood insurance) Available at:

https://www.law.cornell.edu/uscode/text/42/4001 